\title{
Identification, Priorization and Management of Professional Football Clubs' Stakeholders
}

\author{
Nicolas Cicut ${ }^{1}$, Sandra Montchaud ${ }^{1,2}$, Vincent Millereux ${ }^{1}$, Pierre Dantin ${ }^{1}$ \\ ${ }^{1}$ Sport MG Performance, Aix Marseille Université, France \\ ${ }^{2}$ CHERPA, Sciences Po Aix, France \\ Correspondence: Nicolas Cicut, Sport MG Performance, Aix Marseille Université, France.
}

Received: April 17, 2017

doi:10.5539/ibr.v10n7p99

\author{
Accepted: May 19, 2017 \\ Online Published: June 19, 2017 \\ URL: https://doi.org/10.5539/ibr.v10n7p99
}

\begin{abstract}
The aim of this paper is to analyze how professional football clubs manage relationships with their most important stakeholders and their multiple expectations in an efficient framework. Our analysis is based on a case study about 'Olympique de Marseille' (OM) - a recognized French club in Ligue 1 - from a participant observation. The period covers by the study mainly runs from 2004 to 2015 . We adopt a two-step approach consisting first in identifying and prioritizing club stakeholders and then in analyzing the management set up for those who matter most. Stakeholders play an important part in the way club is managed, especially those defined as definitive given their power, legitimacy and urgency attributes. Relationships with the latter can take different forms from involvement to control. Moreover they do not always exist through pre-defined procedures insofar as a significant part of them remains informal. This study enriches the knowledge of the environment of professional football clubs by taking their stakeholders into account. Recommendations are made to improve their stakeholder management practices by considering the specific nature of each relationship, the importance of dialogue in the relationship, the articulation of the formal and informal dimensions of the relationship, the regularity of the relationship and the flexibility of the relationship.
\end{abstract}

Keywords: football clubs, stakeholders, management, case study, France

\section{Introduction}

The stakeholder theory developed by Freeman (1984) rests on the idea that managers within an organization must not only consider the shareholders expectations but also, and more broadly those of a variety of stakeholders. The latter correspond to groups or individuals who can affect or be affected by the achievement of the organization's objectives and thus contribute to define its overall performance. Freeman links the utility of a new managerial paradigm to the changes - internal and external - the firm must face. This approach offers very interesting analytical perspectives and is especially efficient in the study of various types of organizations, including professional football clubs. Changes experienced in the football area particularly justify the recourse to this approach. As mentioned by Senaux (2011), while initially clubs were non-profit associations with sports objectives, they are now commercial firms and football has become a merchandise. It appears that this new logic has not replaced but co-exists with the previous one. Added to this is the social function of football clubs (Sugden, 2002). The crossing of all these dimensions - sporting, economic and social - leads clubs to deal with a large number and a diversity of actors. This contributes to make club's governance more complex, hence the necessity of a stakeholder management.

The literature is interested in identifying the football clubs stakeholders (Boon, 2000; Meyssonnier and Mincheneau, 2013), in prioritizing them in order to highlight those who «count » the most and to which managers have to give their utmost attention (Senaux, 2004, 2008) and in studying their management either in a general perspective of governance (Michie and Oughton, 2005), or more specifically with the study of a distinct stakeholder (Healy and McDonagh, 2013) or the treatment of a precise question related to social responsibility (Breitbarth and Harris, 2008; Walters and Chadwick, 2009; Walters and Tacon, 2010), to the construction of a stadium (Walters, 2011), to the creation of value (Paché and N'Goala, 2011), to the control of the clubs market value volatility (Sarikaya et al., 2012) or to information (Morrow, 2013). Most of these studies were focused on British clubs (Michie and Oughton, 2005; Walters and Chadwick, 2009; Walters and Tacon, 2010; Walters, 2011; Healy and McDonagh, 2013; Morrow, 2013). The other ones were based on French (Senaux, 2004, 2008) and 
Turkish (Sarikaya et al., 2012) clubs or on a broader sample of European (Paché and N'Goala, 2011) or World (Breitbarth and Harris, 2008) clubs.

Thus to the best of our knowledge, only Senaux $(2004,2008)$ studies French professional football clubs within an explicit stakeholder approach, but he considers a limited number of stakeholders and only performs their prioritization. In another work (2011), the author outlines the governance implications of institutional pluralism of football clubs but he does not provide a response to these implications; thus opening up new perspectives for future research on clubs' governance and management. Therefore the objective of our paper is to complete and enrich the analysis of the French professional football clubs' governance and management following Senaux' reflections. We will seek to provide answers to the following question: how can clubs manage relationships with their most important stakeholders whose expectations are multiple and varied in an efficient framework? To do this, we will begin with stakeholders identification and prioritization that constitutes a necessary preliminary step before looking at managerial aspects. Our analysis will be based on a case study. We chose 'Olympique de Marseille' $(\mathrm{OM})$ which is the most successful French club (most national trophies and only French club to win the Champions League). OM also has the largest fan base and one of the biggest budgets in Ligue 1. The period covers by the study mainly runs from 2004 to 2015 and is prior to the change in ownership and management in 2016.

The rest of the article will be structured as follows. In the second part, we will present the general stakeholder approach. In the third part, we will focus on the applications of this analytical framework to football clubs. In the fourth part, we will specify our research objective given the existing literature and our methodology to fill literature gap concerning French football clubs. In the fifth and sixth parts, we will report our results and discuss them. We will first identify exhaustively professional football clubs' stakeholders and highlight those to which the clubs' managers should pay the most attention. Then we will analyze the relationships with those which are considered as the most important, characterize the management set up for them and make some managerial recommendations. In the seventh and last part, we make some concluding remarks.

\section{The Stakeholder Approach}

As mentioned in the introduction, the stakeholder ${ }^{1}$ theory was developed by Freeman (1984) from the idea that managers must not only take into account the shareholders expectations, but more generally, those of a number of the organization's stakeholders. Stakeholders are defined as groups or individuals who can affect or are affected by the achievement of the organization's objectives. They must be considered because they are known to contribute, to varying degrees, to the determination of the overall performance. For Freeman, a new managerial paradigm has become necessary to cope with internal and external changes. This approach has had considerable further development. Two main (and necessarily linked) issues are addressed in the literature.

The first issue concerns the identification of the stakeholders (what actors should be considered as an organization's stakeholders, and what do they expect from it?) and their eventual prioritization (which stakeholder deserves special attention from the organization?) (Mitchell et al., 1997; Phillips, 2003a, 2003b). Several stakeholder classifications can be found in the existing literature. Here are some of them. Freeman (1984) considers stakeholders who are concerned by an internal change, i.e. who are considered as being part of the company main managerial vision (employees, owners, customers, suppliers) and those who are involved in an external change originating in the company's environment and affecting its capacity to adapt to internal changes (competitors, governments, consumer advocates, environmentalists, special interest groups, media). Besides, a distinction is usually made between internal stakeholders who remain within the company's boundaries (owners, directors, employees) and external stakeholders outside the company itself (competitors, consumers, governments, pressure groups, media, etc.) (Caroll and Näsi, 1997). Stakeholders are also called primary stakeholders if they have a contractual and formal relationship with the company and appear as essential to its survival (owners, employees, suppliers, clients) and secondary stakeholders for the other cases (competitors, other consumers, governments, pressure groups, media, etc.) (Carroll, 1991; Carroll and Buchholtz, 2000; Clarkson, 1995; Gibson, 2000; Weiss, 1994). We can further distinguish voluntary stakeholders who take a risk by establishing a particular relationship with the company, such as a financial or human investment, and

\footnotetext{
${ }^{1}$ According to Freeman (1984), the term «stakeholder » was first used in 1963 during a communication at the Stanford Research Institute. The choice of the term revealed a wish to echo the traditional «stockholder » by indicating that other parties had a «stake » in the firm. However, the approach seems to originate in Dodd's (1932) and Barnard's (1938) studies who both underline the necessity to balance the competing interests of the firm participants so as to maintain their cooperation (Mercier, 2001).
} 
involuntary stakeholders who are just exposed to the consequences of the company activities (Clarkson, 1994).

It is possible to go beyond a simple identification and a general classification by hierarchizing the stakeholders according to the degree of attention that must be given to them by the managers. In the literature, there are different priorization models among which those of Eden and Ackermann (1998) and Mendelow (1991) based on criteria such as power and interest, this of Anderson et al. (1999) related to power and support/opposition, this of Mitchell et al. (1997) referring to the criteria of power, legitimacy and urgency. The latter is the most recognized in the academic community. Power refers to the fact that some stakeholders may lead managers to do something they would not have done otherwise (Dahl, 1957; Mitchell et al., 1997; Pfeffer, 1981; Weber, 1947). Three different types of power are distinguished according to how it is exercised: coercive power based on physical resources (force, violence or restraint), utilitarian power based on material and financial resources, and normative power based on symbolic resources (Etzioni, 1964). Legitimacy refers to a generalized perception or assumption that the actions of an entity are desirable, proper, or appropriate within some socially constructed system of norms, values, beliefs, and definitions (Mitchell et al., 1997; Suchman, 1995; Weber, 1947). The social system in which legitimacy is obtained is a system with multiple levels of analysis: individual, organizational and societal (Wood, 1991). Urgency corresponds to the level of immediate attention required to answer some of the stakeholders' requests (Mitchell et al., 1997). It can be assessed through time sensitivity - the degree to which managerial delay in attending to the claim or relationship is unacceptable to the stakeholder - (Eyestone, 1978; Wartick and Mahon, 1994), and criticality - the importance of the claim or the relationship to the stakeholder - (Hill and Jones, 1992; Williamson, 1985). This leads to seven stakeholder categories according to the presence of one, two or three attributes (Figure 1) $)^{2}$. Stakeholders who have only one attribute are considered as «latent» and of low importance for managers. According to circumstances, they can be " dormant», « discretionary » or « demanding » stakeholders. Stakeholders that have two attributes are called « expectant» and are of moderate importance. They include «dominant», « dependent» and «dangerous » stakeholders. Stakeholders with the three attributes are considered as «definitive» and are postulated of high importance. Managers give priority to their claims and the decisions made necessarily take into account their expectations.

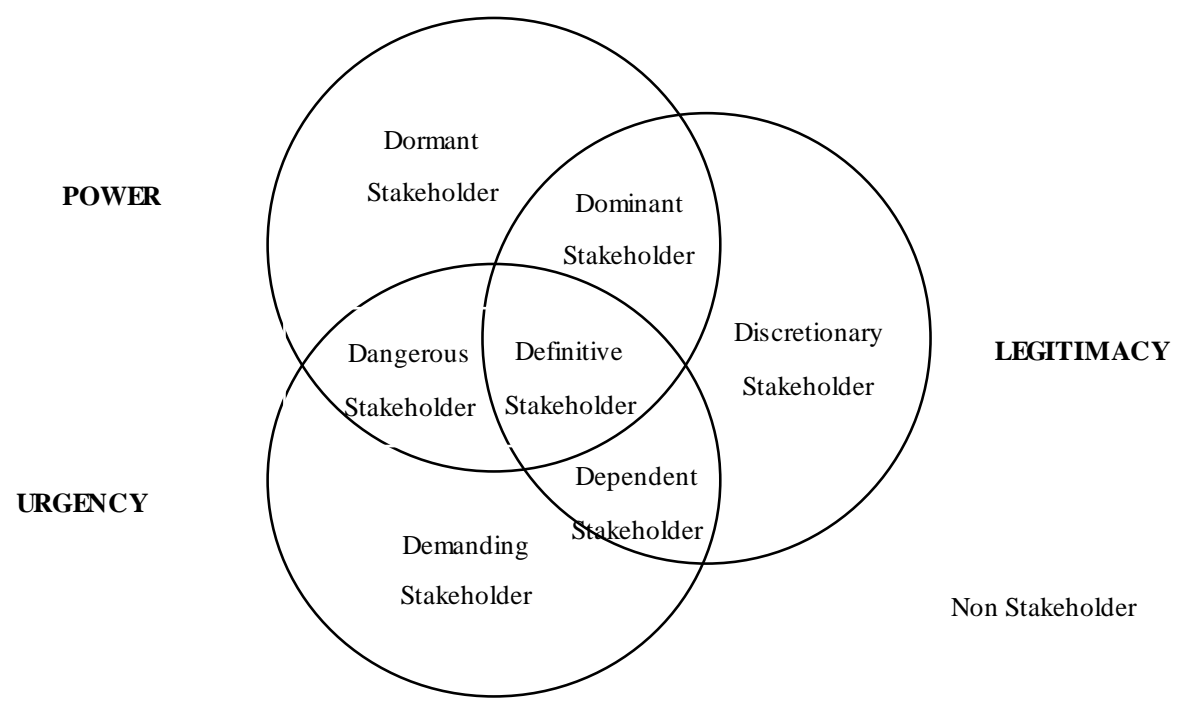

Figure 1. Stakeholder typology according to the presence of power, legitimacy and urgency attributes (source: Mitchell et al., 1997)

The other central issue is stakeholder management. The latter can take the form of risk management (labor input, regulations, etc.) to limit reputation damage or financial sanctions for example (Friedman and Miles, 2006). In a more positive way, stakeholders are viewed as important elements of company strategy, in gaining a competitive advantage and, in fine, to create value and performance (Freeman, 2006; Post et al., 2002). What is the best possible way to manage stakeholders? For Freeman (1984), good management rests on several basic principles

\footnotetext{
${ }^{2}$ For the authors, individuals or entities with none of these attributes are not stakeholders or simply potential stakeholders.
} 
such as the managers capacity to take into account the firm's actions on its stakeholders as well as the potential effects of the stakeholders actions on the firm, their capacity to understand their expectations, behaviors and values and their context, to consider the firm mission, to study the firm relationships with the stakeholders, to analyze the way the firm's strategy takes stakeholders into consideration, or to balance the various stakeholders' interests through time. Stakeholder management therefore requires the conception of models to manage a number of actors, objectives and relationships in a strategic mode (Freeman and McVea, 2001). One should also note that this type of process can be undertaken in a broad perspective or for a specific issue as that of firm social responsibility (Freeman and McVea, 2001).

Svendsen (1998) insists on the possibility for firm leaders to set collaborative relationships with some stakeholders as important elements of general strategy. Bridoux and Stoelhorst (2014) consider that firms face stakeholders that are either reciprocal stakeholders, who do care about fairness, or self-regarding stakeholders, who only care about their personal payoffs and do not value fairness as such. For efficiency purposes in attracting, retaining, and motivating stakeholders to create value, the authors recommend a management focused on the fairness approach for reciprocal stakeholders and a management-based arm's-length approach for self-regarding stakeholders with high bargaining power. For Harrison and St John (1997), stakeholder management rests on a conception of partnership that implies communication, negotiation, contracts, relationship management and motivation management, with these entire aspects bond together by corporate strategy. The authors $(1996,1997)$ distinguish two basic postures for stakeholder management: « buffering » and « bridging ». The first contains the effects stakeholders have on the firm, notably by raising barriers between the firm and some of its external stakeholders. The latter consists in initiating a strategic partnership, which requires the recognition of common objectives and the lowering of the barriers around the organization. Partnership is proactive and based on interdependence. Low and Cowton (2004) highlight two central elements of a stakeholder management strategy: engagement and participation. The implementation of engagement mechanisms does not imply any influence on corporate governance nor any participation in the decision process. Participation is what allows some stakeholders to play a part in the decision making process. This could translate into the integration of stakeholders within a firm governance bodies. More precisely, Friedman and Miles (2006) define twelve types of practices: manipulation, therapy, informing, explaining, placation, consultation, negotiation, involvement, collaboration, partnership, delegated power and stakeholder control. If we consider the two extreme categories, manipulation aims at misleading the stakeholders and is characterized by a one-way dialogue and stakeholder control corresponds to the case where stakeholders have majority control on the decision process. For Walters (2011) who combines the approaches of Low and Cowton (2004) and Friedman and Miles (2006), the first seven categories highlighted by the latter constitute different degrees of engagement and the following five categories correspond to different levels of participation.

\section{Applications of the Stakeholder Approach to Professional Football Clubs}

The stakeholder approach has been used to study various types of organizations, including professional football clubs. These studies concern the two axes seen previously in the general literature: stakeholders identification and prioritization on the one hand, and stakeholder management on the other hand.

When stakeholders are mentioned in the literature on football clubs, these are often simply identified or hastily classified. For example, it is the case in Boon (2000) work concerning English clubs. The identified stakeholders are the Premier Football League, the Football Association, FIFA (Fédération Internationale de Football Association), UEFA (Union of European Football Associations), European clubs, employees, players and agencies, other clubs, fans/consumers, the community, commercial partners, media, broadcasters, the public, the government and review bodies. Another example is that of Meyssonnier and Mincheneau (2013) concerning French clubs who distinguish primary (shareholders, players, spectators) and secondary stakeholders (Ligue de Football Professionnel (LFP), Fédération Française de Football (FFF), UEFA, local authorities, support association, amateur world) without relying on a solid method for prioritizing them. Indeed, the authors indicate only that primary stakeholders are those whose involvement in the club's life is required to some degree to attain success.

Senaux $(2004,2008)$ goes further by establishing a real prioritization of a number of French professional football clubs stakeholders from an accurate method. The study takes into account seven categories of stakeholders: shareholders, players, support association, professional league/federation, local authorities, spectators/supporters and TV channels/sponsors. Other stakeholders - media, players agents, the European Commission and the State - are simply mentioned and left aside for they are either considered as secondary and not so important, or considered as being taken into account more likely by the federation, the league or professional groups/associations. Based on the power, legitimacy and urgency criteria defined by Mitchell et al. (1997) and on 
the interviews of different stakeholders - including clubs officers - for two Ligue 1 and one Ligue 2 clubs, the author concludes that, among the examined stakeholders, the most important ones - considered as unambiguously « definitive »-, towards which attention should be directed, are the shareholders and the players. Supporters can also be a priori definitive stakeholders but in some situations only dominant or dangerous (spectators are not qualified by the author). The league and the federation are considered as dormant, dominant or definitive stakeholders depending on situations. It is the same for the support association. Local authorities are classified as discretionary stakeholders and TV channels as dormant or dominant (sponsors are not qualified).

Some works studying professional football clubs from a stakeholder perspective tackle the management issue in a rather general way. For example, Senaux (2011) is interested in the implications of the development of a commercial logic in French professional football on club governance and management but does not, however, provide a response to these implications. For their part, Michie and Oughton's works (2005) on the governance of English football reveals that good governance requires that clubs communicate not only with their shareholders, but also with other stakeholders such as their employees, their clients, and local community representatives. The relationship with the supporters in particular is important and differs from the usual relationship between a firm and its clients. It rests on communication with supporters groups, supporters trusts, supporter-elected board directors or fan forums in order to favor their involvement.

Other studies adopt a managerial point of view by focusing on a specific type of stakeholder or on a specific issue. In the research led by Healy and McDonagh (2013), attention is focused on a single stakeholder through the study of a football fans virtual community in the case of Liverpool FC. Managers can encourage fans involvement by facilitating dialogue and collaboration in a desire to understand their expectations and to achieve objectives in a brand culture and value co-creation perspective.

Among works dealing with a specific issue, some of them focus on social responsibility. This is the case for Breitbarth and Harris (2008) for different types of sports organizations - professional football clubs, professional football leagues and federations - located in England, Germany, Japan and the United States. The authors present a conceptual model that describes the creation of value for external stakeholders: financial value (e.g., for television channels, sponsors and sporting goods manufacturers), cultural value (e.g., for local communities), human value (e.g., for non-governmental organizations) and reassurance value (e.g., for economic and political actors and the population). From the study of Charlton Athletic and Brentford football clubs which have established a charitable structure involved in socially responsible activities in the areas of health, education, social inclusion and community integration, Walters and Chadwick (2009) emphasize the strategic advantages (the removal of commercial and community tensions, reputation management, brand building, local authority partnerships, commercial partnerships, and player identification) that a football club can draw from the implementation of citizenship-orientated activities through a stakeholder engagement model based on the creation of a community trust model of governance. Walters and Tacon (2010) also focus their attention on how the concept of social responsibility can be implemented by sports organizations through stakeholder management strategies in the UK football industry. Starting from the identification of pertinent stakeholders, the authors examine the actions and responses of organizations as well as stakeholders.

On another subject, Walters (2011) studies how the English club, Arsenal FC, has established a stakeholder management model to deal with the construction of its new stadium - Emirates Stadium -. Based on resident consultations, a communication strategy, a Stadium Liaison Committee, a Stadium Management Plan, and supporter consultations, the management of the stadium construction showed the engagement of the club stakeholders but few opportunities for participation and for involvement in the decision making process. For their part, based on a study of European clubs, Paché and N'Goala (2011) focus on the value creation strategies implemented by the clubs directors, players and fans. These strategies aims the development of brand equity, player-capital and customer equity, especially through marketing policies that seek to promote the links that exist between the three, but the appropriation of the consequently created value is not equal for all of the main actors, in particular for the supporters. Sarikaya et al. (2012) address a different issue: the question of the usefulness of stakeholder management and corporate reputation to control the volatility of sports corporations market value in the case of four listed Turkish clubs (Beşiktaş, Fenerbahçe, Galatasaray and Trabzonspor). The authors emphasize the fact that corporate reputation is closely linked to stakeholder management and that these two dimensions are of paramount importance for the clubs success, for their financial performance and to control the volatility of their market value. For his part, Morrow (2013) deals with the issue of company information especially financial information - in connection with stakeholders (investors, lenders, employees (players, staff...), supporters and the football governing bodies (league, UEFA)) on the basis of British football clubs. It appears that clubs should extend information beyond the economic and financial aspects especially towards a 
social dimension in accordance with the different areas of clubs performance and the consequently expansion of the scope of their responsibility.

\section{Research Objective and Methodology}

Our research objective is to enrich the reflections on French football clubs with regard to their stakeholders and to fill literature gap. Firstly, it is to complete and precise Senaux's $(2004,2008)$ stakeholder identification work by taking into account a larger set of stakeholders and by considering each of them individually, i.e. for example by distinguishing professional league and federation. Secondly, it is to complete and discuss his stakeholder priorization by including in the analysis all the stakeholders previously identified - and not limited to a small number of stakeholders -. Thirdly, it is to fill the literature gap related to French football clubs' stakeholder management. In fact, most research on football organizations under a stakeholder management perspective concern British clubs. Senaux (2011) mentions this issue for French football clubs by simply opening up new perspectives for future research on clubs' governance and management. In order to limit the amount of work, we will characterize the club practices for the most important stakeholders that will be identified beforehand. So our research will strive to answer the two following questions: which stakeholders «count » the most and deserve special attention from the organization's managers and which mechanisms are put in place to manage the relationship with them? To provide some elements of response, we will perform a case study.

The case study is a widely used method in research particularly in social science (Denzin and Lincoln, 1994; Eisenhardt, 1989; Stake, 1994; Yin, 2011, 2013). This method is especially efficient to study situations the researcher has no control on (Yin, 2013), as is our present case because the way officers administrate a club is hardly observable from the outside. Our case study is instrumental (Stake, 1995) as the case studied helps give an o verview of the object of the study, i.e. the practices of professional football clubs. It is conducted towards generalization in reference to a specific context generalization (David, 2004) that corresponds to the other professional football clubs. One should note that the very idea of generalization is questioned by Moriceau (2003) who prefers the notion of repetition. This would avoid the eagerness towards generalization by giving priority to a certain consistency from one case to another. It would then be possible to recognize an unchangeable singularity in one case without renouncing to a knowledge applicable to other cases (Moriceau, 2003). In other words, we must recognize the existence of almost universal recurring practices within singular processes. We are then facing a singular replica of an analogous problem (Moriceau, 2003). For Ayerbe and Missonier (2007), the idea is not to study a case but to study the phenomena and processes it highlights. Our case study is in this perspective.

The completion of a case study is based on four steps: research design, case selection, data collection and analysis mode (Ayerbe and Missonier, 2007). The architecture of a research refers to the theoretical and analytical framework (Yin, 2013). It expresses how the researcher will explore the subject (Ayerbe and Missonier, 2007). In line with the questions underlying our research, we will adopt a two-step analytical process. The first analytical step will consist in the club stakeholder identification and priorization. To do this, we will proceed by distinguishing the internal and external stakeholders in reference to Carroll and Näsi’s (1997) classification and by highlighting their expectations. This will bring more clarity to the stakeholders presentation. Then as Senaux (2004, 2008) did, we will choose Mitchell et al.'s (1997) method to prioritize the identified stakeholders and we will compare our respective results. The second analytical step will consist in the examination of the club stakeholder management. For each stakeholder qualified as definitive, we will attempt to characterize the club practices in reference to the various types of stakeholder management defined by Friedman and Miles (2006). Discussion will mobilize more widely extent literature and recommendations will be made.

The selection phase requires to be cautious of possible biases related to the sample, in particular the selection effects from the researcher (Drucker-Godard et al., 1999). Among the clubs in Ligue 1 in France, we chose to study OM. The club is over one hundred years old and has a rich success history. Our choice is particularly justified by the fact that it is the most successful French professional club: eleven French League titles ${ }^{3}$, ten French Cup titles, three League Cups, two Champions Trophies and the only French club to have won the Champions League title. Its turnover of 109.7 million Euros for the 2014/2015 season makes it one of the biggest budgets in Ligue 1 and one of the top 40 clubs in Europe. It is also the French club with the largest fan base. It should be noted that the club legal structure is a commercial firm - Sociéte Anonyme Sportive Professionnelle (SASP) - combined with a support association affiliated with the FFF.

\footnotetext{
${ }^{3}$ OM claims eleven French League titles, two of which are controversial, the 1929 one (before professional era) and 1993 (OM was stripped of their title by the LFP after the OM/Valenciennes case).
} 
The information used in this study mainly comes from a participant observation (Adler and Adler, 1987; Brewer, 2000; Lapassade, 2001; Soulé, 2007) by three of the authors who have contributed to the club's life by holding executive (general secretary and vice president of the Management Board between 2005 and 2006 and member of the Supervisory Board from 2004 to 2012), sporting and research (player between 1994 and 2004, research fellow from 2010 to 2011 and sponsored PhD student from 2012 to 2015) and counseling (consultant on the training center strategy and policy and on the SASP human resources policy from 2004 to 2010) positions. In the literature, it is sometimes preferred to call such method an observant participation to stress the importance of long-term involvement, the preponderance of participation over observation or the transition from pure participation to observation via a conversion to research (Soule, 2007). The third case corresponds to the situation of these three authors mentioned above who are today university professor, $\mathrm{PhD}$ student and associate senior lecturer. Brewer (2000) in particular considers the use of an existing role to undertake research in a familiar environment as characteristic of an observant participation. However, many works considered as participant observation have used this method to enter a field (Soulé, 2007). This source of data was supplemented by the examination of reports by Deloitte (2015) and DNCG - Direction Nationale du Contrôle de Gestion - (2015) and the LFP website (www.lfp.fr). Thus the variety of sources of information and data collection methods was privileged (Miles and Huberman, 2003). The study mainly covers the period from 2004 to 2015 before the ownership and management change in 2016. We extend our sincere thanks to the former management of the club, especially the ex-general secretary, for his support.

The analysis of all qualitative data collected was carried out by means of a classical content analysis widely used in the literature (Krippendorff, 2003; Robert and Bouillaguet, 1997). This consists in transposing the data and treating them according to a predefined analysis grid which corresponds to a « closed procedure », a «deductive approach of data translation» (Andreani and Conchon, 2005). Information will be treated so as to allow the identification of stakeholders and their expectations, their characterization according to the chosen typology and the highlighting of the management set up for them.

\section{Results and Di scussion on Identification and Prioritization of Club Stakeholders}

Who are the actors that influence and are influenced by a professional football club? As mentioned previously, we will distinguish internal and external stakeholders, which corresponds to an usual and practical classification (Carroll and Näsi, 1997). Then we will prioritize all stakeholders identified according to Mitchell et al. (1997) method based on power, legitimacy, urgency criteria.

\subsection{Identification of Club Stakeholders}

\subsubsection{Internal Stakeholders}

While Senaux $(2004,2008)$ only considers three internal stakeholders - shareholders, players and the support association - we choose to take a larger number of stakeholders into consideration to have a complete view of the actors within a club. Table 1 presents a list of all of them and indicates their main expectations.

Table 1. Internal stakeholders and their main expectations

\begin{tabular}{|c|c|c|c|}
\hline Internal stakeholders & Main expectations & Internal stakeholders & Main expectations \\
\hline Owners & $\begin{array}{l}\text { Sports, economic, financial, } \\
\text { social, media and political }\end{array}$ & Team collaborators & Sports \\
\hline Directors & $\begin{array}{l}\text { Sports, economic, financial, } \\
\text { media and political }\end{array}$ & Administrative employees & Financial and social \\
\hline Coaches/General managers & Sports, financial and media & Support association & Sports, societal and values \\
\hline Players & Sports, financial and media & Youth academy & Sports and economic \\
\hline Technical and medical teams & Sports & Volunteers & Recognition \\
\hline
\end{tabular}

Club owners are natural or legal persons. On the period covers by the study, OM is owned at $99.7 \%$ by Eric Soccer, a holding of the Louis-Dreyfus family. Rather few owners have a direct responsibility in the club management. OM is in this case with Vincent Labrune as its chairman from June 2011 to July 2016.

On the sporting aspect, coaches can be placed under the authority of a general manager or combine both functions. For example, the coach during the 2014/2015 season, Marcelo Bielsa, had extensive functions. Players are responsible for sports performance. OM has a group of 25 to 30 players registered with the LFP over the past seasons. Technical and medical teams include on the one hand the assistant coaches, goalkeeper coach, fitnes s coaches, the head of recruitment and scouts and, on the other hand, doctors, physiotherapists, osteopaths, sports therapists, podiatrists, nutritionists, etc. At OM, these teams are made of around fifteen people. The team collaborators (team manager, team coordinator, kit man, etc.) assist the team on a daily basis. There are between 10 and 12 team collaborators at $\mathrm{OM}$. 
Administrative employees - human resources, marketing, communication, finance, etc. - are another internal stakeholder. They are present in both constituent structures of clubs, namely the corporate structure and the support association. At the end of 2015, OM has 25 administrative employees in the association and around 80 in the corporate structure. The latter are divided into the following departments: human resources (2), secretariat and direction assistance (2), general services - among which infrastructure management - (6), financial department (6), security department (3), legal department (2), media department (31), communication department (7), marketing and trade operations department (24).

The support association is the historical entity of the club, holds the club's FFF registration number, registers teams in national competitions and owns the club logo, color code and slogan, which makes it especially important to the corporate structure. Depending on clubs, the youth academy is attached either to the support association or to the corporate structure. At OM, it is connected with the support association and funded by the corporate structure directly via objectives agreements and indirectly as part of the dedicated staff is employed by the corporation. In addition, it has its own infrastructures (sports, accommodation, academic and medical facilities).

Volunteers are essential to a club's activity, and are attached to the association. OM has several dozens of volunteers. The club relies on them for tasks such as detecting and recruiting players for the youth academy and football school, organizing tournaments and camps throughout the year, and coaching youth teams. Volunteers receive material compensation in the form of equipment, tickets to the stadium and a symbolic retribution by their belonging to the locally highly valued « $\mathrm{OM} »$ institution.

\subsubsection{External Stakeholders}

Our identification of external stakeholders is both more comprehensive and accurate than the one previously made by Senaux $(2004,2008)$ who studied only four categories - league/federation, local authorities, spectators/supporters and TV channels/sponsors - and mentioned four others - the press, players agents , the European Commission and the State - without investigating them. For our part, we choose to work on a more thorough picture of external stakeholders and to consider them precisely and indi vidually so as to highlight their specific characteristics. Indeed, we will examine the league and the federation separately, as we will do for TV channels and sponsors, and we will distinguish cities from other local authorities and spectators from supporters groups. External stakeholders and their expectations are presented in table 2.

Table 2. External stakeholders and their main expectations

\begin{tabular}{|c|c|c|c|}
\hline External stakeholders & Main expectations & External stakeholders & Main expectations \\
\hline FIFA & $\begin{array}{l}\text { Football development } \\
\text { and regulatory }\end{array}$ & Coaches union & $\begin{array}{l}\text { Respect, promotion and defense of } \\
\text { the profession }\end{array}$ \\
\hline UEFA & $\begin{array}{l}\text { Football development } \\
\text { and regulatory }\end{array}$ & Players union & $\begin{array}{l}\text { Respect, promotion and defense of } \\
\text { the profession }\end{array}$ \\
\hline FFF & $\begin{array}{c}\text { Football development } \\
\text { and legal }\end{array}$ & Referees union & $\begin{array}{c}\text { Respect, promotion and defense of } \\
\text { the profession }\end{array}$ \\
\hline LFP & $\begin{array}{l}\text { Football development, } \\
\text { regulatory and } \\
\text { economic }\end{array}$ & Agents union & Legitimacy and recognition \\
\hline DNCG & Regulatory & Spectators & Sports and entertainment \\
\hline EU & Legal and regulatory & Supporters groups & $\begin{array}{l}\text { Sports, entertainment, social and } \\
\text { identity }\end{array}$ \\
\hline Ministry of Sports & $\begin{array}{l}\text { Football development, } \\
\text { legal and regulatory }\end{array}$ & Media & $\begin{array}{l}\text { Audience/visibility, sports, } \\
\text { entertainment, economic and } \\
\text { financial }\end{array}$ \\
\hline $\begin{array}{l}\text { Ministry of Economy and } \\
\text { Finance/Ministry of Labor }\end{array}$ & Legal and financial & Suppliers & $\begin{array}{l}\text { Visibility/image, economic, } \\
\text { financial and social }\end{array}$ \\
\hline Home Office & Regulatory & Clients & $\begin{array}{l}\text { Visibility/image, economic and } \\
\text { financial }\end{array}$ \\
\hline City & $\begin{array}{l}\text { Sports, political, image } \\
\text { and territorial } \\
\text { development }\end{array}$ & Competitors & Sports and entertainment \\
\hline Other local authorities & $\begin{array}{l}\text { Political, image and } \\
\text { territorial development }\end{array}$ & $\begin{array}{l}\text { Environmental, residents } \\
\text { and territory defense } \\
\text { associations }\end{array}$ & $\begin{array}{c}\text { Compliance with laws and rules } \\
\text { and defense of the association's } \\
\text { interests }\end{array}$ \\
\hline Players agents & Sports and financial & Social associations & $\begin{array}{l}\text { Defense and promotion of the } \\
\text { association's social object }\end{array}$ \\
\hline Chairmen union & $\begin{array}{c}\text { Professional clubs } \\
\text { development }\end{array}$ & Financial community & $\begin{array}{l}\text { Funding in compliance with the } \\
\text { rules set by the supervisory bodies }\end{array}$ \\
\hline
\end{tabular}


FIFA, at the head of world football, leads and guides the practice in a strategic perspective. Clubs must comply with the rules of the game established by FIFA via the International Football Association Board (IFAB). UEFA is itself responsible for the development of football in Europe under the authority of FIFA. Ligue 1 clubs, like those in other championships, are directly related to UEFA for the competitions it organizes (Champions League, Europa League) and, in a less direct way, by the specifications it has established to organize and host these competitions. The FFF, in charge of amateur football, in connection with the associations, and the LFP, in charge of organizing professional football championships, are two key stakeholders for professional clubs. The organization and marketing of the competitions, income distribution, clubs promotion, etc., are core tasks of these bodies. All professional clubs, including OM, are permanently connected to these institutions. Vincent Labrune was vice-chairman of the LFP board. There is also the DNCG whose main objective is to ensure the sustainability and fairness of the competition, particularly by verifying that each club's sports investments do not exceed its financial capacity. Every year, like all French professional clubs, OM must give a balance sheet and operating account for the past season and a projection for the coming season to this institution. The DNCG has the power to demote to a lower division a club which management does not fit the enacted framework.

By its legislation, the European Union (EU) has an impact on clubs, especially on transfers as shown by the 1995 Bosman ruling. Before this date, OM plays with only three foreign players on the game sheet, while all the other players were eligible to play for the national squad. Nowadays, and for the same competition, there could be no eligible player at all. At national level, the State, through its various ministries, lays down rules to which all Ligue 1 clubs must comply. The Ministry of Sports periodically sets an objectives agreement with the FFF and contributes to the legislation of professional sports. The Ministry of Economy and Finance and the Ministry of Labor define tax rules and social laws. The Home Office regulates match organization from a security point of view. Some OM games (especially against Paris-Saint Germain (PSG)) are considered as high-risk and mobilize large numbers of police officers and stewards. In addition, the club is subject to the minister's decisions concerning the contingent of its supporters for away games.

Local authorities (city, county, region, community of communes, community of agglomerations) provide direct funding - subsidies - and indirect funding - purchase of advertising space, etc. - to clubs. Authorities also often own the sporting facilities and therefore are involved in their management. As far as OM is concerned, the Velodrome Stadium is owned by the City of Marseille and its refurbishment for Euro 2016 falls within a public-private partnership between the City of Marseille and Arema. OM is considered as the resident club but is only tenant, while the club wanted to operate the stadium. The Robert Louis-Dreyfus training center, originally the property of the City of Marseille but in which the club had invested, was recently bought by OM for 6.5 million Euros.

Players agents, key actors in the world of professional sports, represent the interests of hundreds of players and coaches. The extensive player portfolio of some agents gives them a prominent position. In OM's case several world renowned agents are involved each year - summer and winter transfer markets - in the transactions. In the last five years the club has recorded a minimum of 12 moves per season.

One must also consider the various unions: the chairmen unions (Première Ligue and Union des Clubs Professionnels de Football (UCPF)), the coaches union (Union Nationale des Entraîneurs et Cadres Techniques professionnels du Football (UNECATEF)), the players union (Union Nationale des Footballeurs Professionnels (UNFP)), the referees union (Syndicat des Arbitres de Football Elite (SAFE)) and the agents unions (Union des Agents Sportifs du Football (UASF) and Syndicat National des Agents Sportifs (SNAS)). Unions seek to defend the interests of their members, including salary. Vincent Labrune was a member of Première Ligue.

Spectators are the clubs first customers. During the 2014/2015 season, the total attendance at the Velodrome Stadium was 1009478 people over 19 Ligue 1 matches, meaning an average of 53 130. Supporters groups, who, by essence, are brand partisans and driven by passion, are the ultimate form of structuring in the typology of spectators. OM has nine officially recognized supporters groups accounting for more than 25000 supporters mainly in the north and south stands of the stadium. They organize displays in the stadium and therefore are part of the show and hereby strengthen the club's attractiveness. At OM, the relationship with fans is rather atypical because since the 1980s, they manage the marketing of season tickets for the north and south stands.

The media ensure championship visibility and exposure and help strengthen and develop its social penetration. In addition, the television rights are an important part of the clubs income. For the 2014/2015 season, OM was the club with the second highest retribution and the second most broadcast (behind the PSG): 23 times on Canal ,+ 12 times on Bein Sport 1, for championship games only (LFP). It was also the most present in the written press: 13\% of L'Equipe newspaper front pages (Office de Justification de Diffusion (OJD)) and 75\% more 
presence than any other club in the national press (Datops). It is also the most followed French club on digital media and social networks (4.8 million followers on Facebook and 1.7 million followers on Twitter).

Professional football clubs rely on suppliers for the part of their event organization and promotion activity they want to outsource (logistics, maintenance, cleaning, security, reception, catering, public relations, ticketing, etc.). In some cases, clubs and suppliers operate via the barter exchange model. They are in turn suppliers and customers. Thus, OM uses Etic Group as a supplier for hospitality services and Etic Group is itself a client of the club (seasonal renting of a hospitality box).

Clients are another group of external stakeholders. Among them, sponsorship is an important part of the marketing revenues for professional football clubs, which are an essential part of their total revenues (approximately 30\% for the 2014/2015 season). OM has had around 300 clients over the last five seasons and sponsorship accounted for about 31 million Euros in the 2014/2015 105 million Euros budget.

Competitors can be of different nature. First, there are the other clubs with which the competition is not only on the sports level (national and European competitions, recruitment) but also on the economic level (sponsorship) and media coverage level. Then, competition can also come from other actors who offer sports entertainment other than football or even outside the world of sports. Indeed, OM faces competition with more or less attractive national and European clubs and, outside football, must also cope with other forms of competition such as the one with the Rugby Club Toulonnais on some aspects of its offer.

Environmental, residents and territory defense associations can be an important opposition force against clubs in development, building, refurbishment or rehabilitation programs, like stadiums or training centers, may the clubs be simple tenants, operators or owners of the infrastructures. The association «En toute franchise », representing the interests of independent traders around the stadium, appealed to the Conseil d'Etat against the refurbishment of the Velodrome Stadium and the planning of the stadium surroundings (building of a 25000 sqm mall). Social associations for their part use the clubs opinion leadership to promote, defend and develop the missions of general interest they carry out. OM considers itself as a defender of multiculturalism and anti communitarianism.

Finally, the financial community is able to provide the capital required to develop a significant economic sector (Ligue 1 clubs altogether weigh 1.5 billion Euros (LFP)). However clubs can only be funded by financial institutions in compliance with the rules set by the dedicated supervisory and management bodies.

If this stakeholder identification was performed by highlighting the characteristics of $\mathrm{OM}$, it reflects more broadly the panorama of all Ligue 1 clubs.

\subsection{Prioritization of Club Stakeholders}

Based on Mitchell et al.'s (1997) analytical grid, Table 3 presents the attributes for each of them (except managers themselves) in the OM case.

We clearly identified seven definitive stakeholders, ten dominant, three dangerous, one demanding, and twelve discretionary. In two cases, the classification varies according to individual actors that make up each stakeholder category: definitive/dangerous and definitive/dominant. We believe that our prioritization of stakeholders carried out on the basis of the OM case is in fact valid for all Ligue 1 clubs except in some cases such as the youth academy regarding the power criterion or supporters regarding the urgency criterion.

We can compare our results with those of Senaux $(2004,2008)$ when it is possible because, as previously mentioned, only a few stakeholders are taken into account by the author. If they are similar regarding shareholders and players, they differ somewhat for other stakeholders. The support association is considered by Senaux as a rather dormant stakeholder that can become dominant or definitive. We consider the support association to be dominant. It has legitimacy and its main power lies in owning the club's affiliation number to national competitions. However and according to us its status does not allow it to impose any urgency on SASP OM. For Senaux, the league and the federation are probably dormant but have the ability to become dominant or even definitive. The disassociation of the league and the federation brought us to consider the first as definitive and the second as discretionary. According to us the FFF, which is in charge of amateur football and linked to support associations rather than to professional clubs, cannot really influence clubs. Then Senaux classifies local authorities as discretionary. It seems to us the City of Marseille should be considered differently than other local authorities that we also list as discretionary. Indeed, the City, as the owner of the Stade Vélodrome, undeniably has power and legitimacy, and therefore is classified as dominant. For Senaux, supporters are a priori definitive stakeholders but can in some situations be only dominant or dangerous. In OM's case, supporters are undoubtedly definitive stakeholders but their importance may vary for other clubs depending on the supporters 
groups organization, on numbers, on the amount of passion and support they show or on their presence in the media and their importance in the club's image. According to Senaux, TV channels are dormant and can become dominant if TV rights are commercialized on an individual basis. We believe they are for OM either dangerous or definitive stakeholders depending on their legitimacy. The most renowned and followed mainstream media influence the club's image and notoriety and therefore are treated by the club with special attention contrarily to the multitude of recently born OM centered media which legitimacy is not recognized.

Table 3. Stakeholder attributes and type

\begin{tabular}{|c|c|c|c|c|}
\hline \multirow[t]{2}{*}{ Stakeholders } & \multicolumn{3}{|c|}{ Attributes } & \multirow[t]{2}{*}{ Type } \\
\hline & Power & Legitimacy & Urgency & \\
\hline \multicolumn{5}{|l|}{ Internal } \\
\hline Owners & Yes & Yes & Yes & Definitive \\
\hline Coaches/General managers & Yes & Yes & Yes & Definitive \\
\hline Players & Yes & Yes & Yes & Definitive \\
\hline Technical and medical teams & No & Yes & No & Discretionary \\
\hline Team collaborators & No & Yes & No & Discretionary \\
\hline Administrative employees & No & Yes & No & Discretionary \\
\hline Support association & Yes & Yes & No & Dominant \\
\hline Youth academy & Yes & Yes & No & Dominant \\
\hline Volunteers & No & Yes & No & Discretionary \\
\hline \multicolumn{5}{|l|}{ External } \\
\hline FIFA & No & Yes & No & Discretionary \\
\hline UEFA & Yes & Yes & No & Dominant \\
\hline FFF & No & Yes & No & Discretionary \\
\hline LFP & Yes & Yes & Yes & Definitive \\
\hline DNCG & Yes & Yes & Yes & Definitive \\
\hline EU & Yes & Yes & No & Dominant \\
\hline Ministry of Sports & No & Yes & No & Discretionary \\
\hline Ministry of Economy and Finance, Ministry of Labor & Yes & Yes & No & Dominant \\
\hline Home Office & Yes & Yes & Yes & Definitive \\
\hline City & Yes & Yes & No & Dominant \\
\hline Other local authorities & No & Yes & No & Discretionary \\
\hline Players agents & Yes & No & Yes & Dangerous \\
\hline Chairmen union & No & Yes & No & Discretionary \\
\hline Coaches union & Yes & Yes & No & Dominant \\
\hline Players union & Yes & Yes & No & Dominant \\
\hline Referees union & No & Yes & No & Discretionary \\
\hline Agents union & No & Yes & No & Discretionary \\
\hline Spectators & No & No & Yes & Demanding \\
\hline Supporters groups & Yes & Yes & Yes & Definitive \\
\hline Media & Yes & Yes/No* & Yes & Definitive/Dangerous \\
\hline Suppliers & Yes & Yes & No & Dominant \\
\hline Clients & Yes & Yes & Yes/No** & Definitive/Dominant \\
\hline Competitors & Yes & No & Yes & Dangerous \\
\hline Environmental, residents and territory defense associations & Yes & No & Yes & Dangerous \\
\hline Social associations & No & Yes & No & Discretionary \\
\hline Financial community & Yes & Yes & No & Dominant \\
\hline
\end{tabular}

*: depending on individual media. **: depending on individual clients.

\section{Results and Discussion on the Management of Club Stakehol ders}

In what framework do the relationships between the club manager and the most important stakeholders take place? In other words, what are the mechanisms and processes at the manager's disposal or established by them to deal with these stakeholders expectations (Freeman, 1984)? Our analysis will be limited to only the definitive stakeholders that are unequivocally qualified as such above, i.e. those are the most important to be considered by managers following Mitchell et al.'s (1997) prioritization method. We will attempt in particular to characterize the club practices in reference to the various types of stakeholder management defined by Friedman and Miles (2006): manipulation, therapy, informing, explaining, placation, consultation, negotiation, involvement, collaboration, partnership, delegated power and control. The analysis will mobilize more widely extent literature. This will bring us to make some managerial recommendations that we hope helpful for all professional football clubs. In particular, we will specify the nature of the dialogue with each of the studied stakeholders we advocate. As mentioned by Michie and Oughton (2005), good governance requires that clubs communicate not only with their shareholders, but also with other stakeholders. 


\subsection{Owner}

The relationship between a club director and a club owner (when they are not the same person) is essential. It takes place within the Board of Directors or within the Supervisory Board and the Management Board depending on the legal structure of the club. Between 2001 and 2011, OM was operated according to this last formula. The members of the Supervisory Board were appointed by the majority shareholder. There were seven members on the Supervisory Board and, two to three members on the Management Board. The Supervisory Board met every three months unless an emergency was important enough to provoke an extraordinary meeting. The decision-making process being much shorter, the transition to a Board of Directors reflects the company's wish to facilitate and streamline the relationship between the shareholder and the chairman of the club. The Board of Directors is composed of six to eight members among whom two members represent the employees of the administrative department and attend meetings in an advisory capacity. The Board of Directors meets once every two months. As in any company, the chairman must meet the owner's expectations and may be revoked by the Board of Directors or the Supervisory Board if such is not the case. This is what happened in June 2011 for Jean-Claude Dassier, then chairman of OM, who was dismissed by the Supervisory Board. The shareholder then appointed Vincent Labrune as club chairman and the transition to a Board of Directors mentioned above was made. The relationship between the club chairman and its owner is institutionalized and similar to what happens in any business. Beyond the sporting dimension, economic issues are of utmost importance in the relationship with the owner, and the latter sets the tone. If the former owner - Robert Louis-Dreyfus - tolerated recurring losses, it is quite otherwise with Margarita Louis-Dreyfus who demands a remediation of accounts. Consequently, the club made a 380000 Euros profit for the 2012/2013 season - the first time since 2009 - thanks to the efforts made to reduce spending (especially a $23 \%$ decrease of the payroll compared to the previous season). This consolidation of the club's accounts in the last few seasons however has had a negative effect on the quality of the player capital and on football performances. It should be noted that, in general, unlike traditional companies, profitability is not as important for the club owners whose satisfaction should be considered in other areas. For an owner, the club can be a value-creation and a reputation tool for all his activities and can create a communication and emotional synergy and thus become a powerful means of adherence, contagion, etc. The case of Robert Louis-Dreyfus, OM's owner from 1996 to 2009, shows that two of the Louis Dreyfus Group companies were successively the club's main partner: Neuf Telecom from 2003 to 2008 and Direct Energy from 2008 to 2010. They benefited de facto from the club's likeability and penetration which enabled them to develop their activities more quickly on the club's territory. In 2006, Neuf Telecom chose Marseille as its main call center and customer relations center. The idea of profit maximization clearly does not suit sports organizations in favor of an alternative behavior consisting in maximizing a utility function incorporating other elements, which may be subject to a minimum profit or maximum loss constraint (Goddard and Sloane, 2005; Sloane, 1971, 2006; Zimbalist, 2003).

The relationships with owners correspond certainly to the «control » type of management which is the highest level of participation in Friedman and Miles' (2006) typology. Owners are at the heart of the decision-making process. In this respect the aim for a club director is to keep the owner informed of the club's strategies and policies and to have them validated. At all time the owner's opinion and requirements in terms of sports projects (e.g. choice of the coach), economic matters (e.g. bank guarantee or not) or club development (e.g. training facilities development) must be taken into account. Face to financial and operational difficulties and challenges, it is necessary to improve corporate governance practices, financial reporting and risk assessment procedures (Hamil et al., 2004).

We deduce from this analysis the following recommendations for professional football clubs, including the fact to have more frequent meetings than those officially planned (board meetings...) (Table 4).

Table 4. Managerial recommendations for the stakeholder « Owner»

- Organize meetings with the owner at three key moments of a season: pre-season (sport situation, financial situation), winter break (mid-season appraisal, adjustment of the resources) and end of season (season report, perspectives).

- Maintain dialogue with the owner outside these three key moments, throughout the season via interim reports.

- Depending on current situation, set up regular, possibly daily contacts with the owner (phone, text messaging, videoconference, emails...).

- Improve corporate governance practices, financial reporting and risk assessment procedures (sports and economic). 


\subsection{Coach/General Manager}

Relationships between director and coach/general manager start at the time of contract negotiation, which is a good time to exchange on each other's expectations and which continues over time. Meetings frequency increases in specific situations that concern either the coach/general manager personally like a desire to leave the club, contract ending, salary renegotiation, etc., or more generally the team especially in case of poor performance or for transfers (buying and selling players). At OM, there are consultation meetings every two weeks, and obviously meetings that can be held on a daily basis according to current events. While the assessment of « intrinsic » results is performed by the corporate manager, « technical » assessment goes through procedures that fall within the technicians' expertise: the general manager will discuss with the coach on how all sports issues are conducted. One should note the very important place of informal relationships with the coach, which has advantages but also generates biases. The relationship is based on a collaborative model as this stakeholder is seen as an essential component of the general strategy (Svendsen, 1998).

The management concerning the coach/general manager seems to correspond to the «delegated power » type in reference to Friedman and Miles (2006). Indeed this stakeholder owns the sports expertise which makes them a vital element of the club and the guarantor of its sports policy. This expertise is related to the dynamic social construction of coaching knowledge in a highly competitive environment (Jones et al., 2003) and in particular to the capacity to allow a better team cohesion thanks to higher levels of engagement in social support, training and instruction, positive feedback, and a democratic style (Westre and Weiss, 1991). The club manager therefore delegates sport power to the coach or general manager. In return, the club manager will assess him on his results and will continuously make sure that they match the objectives.

A close and almost permanent (daily) dialogue, often more informal than formal, with this essential stakeholder is necessary (Table 5).

Table 5. Managerial recommendations for the stakeholder «Coach/General manager »

- Plan meetings according to key sports moments: pre-season in June and July (set sport objectives), before the winter break in December (mid-season report, adjustment of the resources and complementary recruiting during the winter transfer market) and end of season in may (season report and preparation for the next season).

- Organize meetings per blocks of about four league games or monthly meetings.

- Have additional meetings according to the evolution of the club's situation (lack of results, ethical issue, contractual situation of the coach/general manager...).

- Create the favorable conditions for the deployment of the coach' sports expertise.

6.3 Players

Like for coach/general manager, on the negotiation phase prior to recruitment is the time for officers to assess the players - essentially financial - expectations and to ans wer them. Then, relationships take place over time and the parties meet more or less frequently depending on performance, contract and transfers. During the period of the contract, it is important for officers to develop and maintain stable and lasting relationships with the players (and their representatives) as they are the centerpiece of the club's performance. Apart from meetings with the players (and their representatives) for salary negotiations, meetings are held on a more informal level. At OM, relationships with players often take place with the general manager, the coach or even the agent. In addition to individual meetings, there are group meetings between the manager and the team during which opinion leaders express themselves on topics such as premiums, crisis situations, etc. To keep players in the best conditions (especially those considered as «star » players with a high potential), OM provides and pays for various services such as luxury concierge service, personal protection services, etc. In the same way as with the coach/general manager relationship, a truly collaborative approach is used towards players as they are at the heart of the club's general strategy (Svendsen, 1998) and as their performances greatly contribute to the club's development.

For the club manager players are both a sports capital and an economic capital which brings to consider the «partnership» type of management mentioned by Friedman and Miles (2006). The aim is to increase the value of the economic capital a player represents and to increase his efficiency on the pitch. The manager must make sure the players respect their sport obligations (individual behavior, collective performance). More generally, in relation with the coach/general manager he must create the conditions for the team success by trying to foster relationships and cooperative behavior among players. Teamwork is viewed as a synergetic process in which the efforts of the cooperative group surpass individual efforts and ineffective communication or lack of trust are considered likely to hinder or not support a team effort (Scarnati, 2001). Team effectiveness can also be 
improved by a better management of team conflicts with personal audit as a tool (Opute, 2012). In an economic point of view, the manager must take into account their contractual situation, aim at maximizing the sports aspects (players are an intangible asset), and include the latter in the club's marketing strategy (market valuation of the image). A strong partnership links the club and the player as the player's good performances not only contribute to the club's good health but also to his own career development.

In this respect, individual and collective meetings should be planned to build and maintain a close relationship and actions must be devised in a team building perspective (Table 6).

Table 6. Managerial recommendations for the stakeholder «Players»

- Organize individual meetings at the three key moments of the season: pre-season (definition of the objectives), winter break (mid-season report, squad adjustment through loan or transfer), and end of season (season report, transfer, contract renewal).

- Organize occasional individual meetings according to the player's contractual situation.

- Plan collective meetings at the key moments of the season, on match day, after remarkable performances or in case of insufficient results.

- Achieve a good distribution of roles and undertake actions in favor of teamwork and conflict management to increase individual and collective performances.

\subsection{LFP}

For definitive external stakeholders that have an essentially regulatory influence on clubs, there is the LFP. The club does not take any specific action to meet this stakeholder's expectations as they are perfectly known and relatively stable over time. The club is simply attentive to its topical requests when a specific problem arises. Some units - general management and the legal department in most cases - are responsible for dealing with its regulatory requirements, which is the case at $\mathrm{OM}$. With the issues and problems that can occur during a season, clubs commission a representative among their members to defend their interests. For example, whene ver one of its members is heard by the LFP Disciplinary Committee, OM sends a representative who is most often the chief legal officer. The relationship with this stakeholder is of the risk management type in order to limit reputation damage or sanctions (Friedman and Miles, 2006).

A «delegated power» characterizes de facto the relationship with the LFP. As the governing body for professional football the latter initiates relationships with clubs. It organizes meetings with all the clubs managers. Moreover and according to circumstances it can plan meetings about commercial, ethical, disciplinary, sports, security... aspects. The club must therefore be available.

To go further, in the aim of maintaining and defending the club's interests, we recommend the manager continuously try to influence the LFP decisions (negotiations and distribution of commercial rights, fixtures, disciplinary decisions...) (Table 7).

Table 7. Managerial recommendations for the stakeholder «LFP»

- Influence and lobby the various LFP committees to preserve the club's interests.

- Request meetings with the decision-makers on specific points (for example, to arrange fixtures before and after European games).

$6.5 D N C G$

Regarding DNCG, the reasoning is similar to that developed for LFP. This stakeholder's expectations are known and stable. The club financial department is responsible for being kept informed of any change in the rules and procedures (transmission of past and projected balance sheets, hearings...) and for preparing the documents that have to be transmitted. The chairman is of course liable of meeting DNCG's expectations. However, some situations may require the intervention of the owner. For example, in June 2001, Robert Louis-Dreyfus, as OM owner (he was also chairman at the time), had to provide a bank guarantee at DNCG's express request, to compensate the past season losses and have the club be authorized to play in Ligue 1 for the following season. As with LFP, the relationship with DNCG is of the risk management type to limit sanctions in case of poor financial management (Friedman and Miles, 2006).

Because of its position in the hierarchy (supervisory and control body for professional football), it is «control» in reference to Friedman and Miles (2006) that seems obvious for the DNCG stakeholder. Management possibilities for this stakeholder are very limited given the binding framework in which the relationship takes place. Indeed the club manager has to provide DNCG with a pre-season projected budget, a mid-season report 
and an end-of-season statement. On DNCG's request, the manager might also have to provide additional accounting documents.

Thus, the only valid recommendation with regard to this stakeholder is to be amenable and cooperative (Table 8).

Table 8. Managerial recommendations for the stakeholder «DNCG»

- Try and establish a trusting relationship with DNCG by providing all necessary elements in due time.

\subsection{Home Office}

Concerning relationships with the Home Office, clubs must be attentive to its topical requests. The clubs chief officer is informed of high-risk matches and of any restriction so that clubs comply with these requirements. OM is one of the most closely watched clubs not only because of the number and versatility of its supporters, but also because of its history with other Ligue 1 sides. Several collaborators have all or part of their mission focused on security during the games, supporters behavior and the club's relationship with the supporters and with the authorities.

We believe the relationship with the Home Office corresponds to the "collaboration » in Friedman and Miles' (2006) typology. The Home Office establishes a classification for high-risk games (supporters and spectators flow management) and asks the clubs to make required arrangements. Clubs have a specific correspondent at the Home Office to discuss decisions.

In these conditions, it is important that the manager answers to the specifications regarding public events safety in a timely and optimal way (Table 9).

Table 9. Managerial recommendations for the stakeholder «Home Office »

- Anticipate potential high-risk games as soon as fixtures are announced.

- Show the Home Office that the club mobilized all necessary resources to ensure that each game takes place under optimal security conditions.

\subsection{Supporters}

Relationships between the club chairman and the supporters groups depend strongly on the club's history and culture. In all cases, it is important to establish good communication with them (Michie and Oughton, 2005). Supporters represent the 12th man of the team in the sense that they are considered to contribute to team performances (Davies et al., 1995) because their encouragements lead players to excel (Svendsen, 1998). Therefore a collaborative relationship must be established with this stakeholder. At OM, meetings are held at the beginning of the season and during special events («risky » away games, finals, etc.). The club and the supporters groups are also in constant and direct contact through some of the club members' functions (employees working for the security service, for example). Moreover, in the case of strong supporters dissatisfaction, clubs directors are forced to see their representatives. For example, in 1999, due to unsatisfactory sports results, Marseille supporters ransacked part of the stand they had been assigned to in the Geoffroy Guichard stadium in Saint-Etienne and a few days later, prevented all access to the Commanderie training center, damaged some of the players' cars and even forced a French international player to hide in a car boot to leave the center. Following this demonstration of anger, the club's directors met the supporters groups at their request to find a form of consensus in order not to jeopardize the club's activity. This example shows the relationship with this specific stakeholder comprises a risk management part that can decisive in some critical situations (Friedman and Miles, 2006). Another event is interesting to understand the nature of the relationship between the club and its supporters. In 2006 for a PSG/OM game, the supporters groups saw the number of seats for visiting fans cut down and later allocated in stands that did not satisfy them in terms of safety. To show his support, Pape Diouf, then chairman of the club, decided to send a team of young players and players lacking regular match action. This decision displeased the LFP and the media as PSG/OM «Classicos » are a highlight of the season and make a record audience. This example illustrates the fact that stakeholder management implies to find a balance between the various interests (Freeman, 1984). This task is particularly difficult because of their potentially large number and their sometimes contradictory and conflicting expectations. It is, for Svendsen (1998), a characteristic ability of successful companies, which does not mean that the interests of all can be satisfied at all time. More generally, the OM case illustrates, albeit in a particularly high degree, the importance of the relationship with the supporters and the fact that this relationship differs from the usual relationship between a firm and its clients (Michie and Oughton, 2005).

For supporters groups the management is on the register of «involvement» in Friedman and Miles' (2006) typology. Supporters groups are at the same time a «dramaturgical» issue (which contributes to the show and 
therefore to writing the games and the clubs history) and an economic issue. They can also be a nuisance for the club. On logistical aspects (preparing fan displays) and security and financial aspects, the manager has to impose very strict specifications to the supporters groups.

In these conditions, it is important to implement mechanisms that favor supporters involvement based on communication (Michie and Oughton, 2005). The set up of a fans virtual community may be a lever on which to play in facilitating dialogue with supporters, especially with the most influential members of the community (Healy and McDonagh, 2013). So the manager must have direct and regular relationships with the legal representatives of the supporters groups and be open to new communication mode (Table 10).

Table 10. Managerial recommendations for the stakeholder « Supporters groups »

- Define a meeting schedule with the supporters groups representatives at key moments of the season: in pre-season to present the club's expectations on various aspects (security, displays...) and plan the following meetings (with the club and team staff), in mid-season for a mid-season report and possible adjustments, and at the end of the season for a season report and corrective action.

- Organize specific meetings (for example before difficult games, or to prepare an important home game).

- Encourage the set up of a fans virtual community.

\section{Conclusion}

It is clear from our research that stakeholders play an important role in how clubs are managed, especially those considered as definitive given their power, legitimacy and urgency attributes. The relationships with the latter, studied in the OM case, can be of different type, ranging from involvement to control. It appears that the club tries as much as possible to take their expectations into account. This is not always done through pre-defined procedures, as a significant part of the relationships remains informal. Stakeholder management recommendations have been made to improve the clubs practices by considering the specific nature of each relationship, the importance of dialogue in the relationship, the articulation of the formal and informal dimensions of the relationship, the regularity of the relationship and the flexibility of the relationship.

Future research could be made to complete this study by analyzing other stakeholders, notably those with two attributes (dominant, dangerous and dependent). It would give a more thorough vision of the variety of actors in a professional club's environment and help appreciate the increased complexity of the clubs' objective function that encompasses multiple arguments (sports, economic, social...) thus reflecting the search for a multidimensional performance accordingly to a variety of stakeholder expectations.

\section{References}

Adler, P. A., \& Adler, P. (1987). Membership roles in field research. Thousand Oaks: Sage Publications. https://doi.org/10.4135/9781412984973

Anderson, S. R., Bryson, J. M., \& Crosby, B. C. (1999). Leadership for the common good fieldbook. St. Paul: University of Minnesota Extension Service.

Andreani, J. C., \& Conchon, F. (2005). Les méthodes d'analyse et d'interprétation des études qualitatives, un état de l'art en marketing. $4^{\text {ème }}$ Congrès International des Tendances du Marketing, 21-22 janvier, Paris.

Ayerbe, C., \& Missonier, A. (2007). Validité interne et validité externe de l'étude de cas: principes et mise en œuvre pour un renforcement mutuel. Finance Contrôle Stratégie, 10(2), 37-62.

Barnard, C. I. (1938). The functions of the executive. Cambridge: Harvard University Press.

Boon, G. (2000). Football finances: too much money? In: Hamil S., Michie J., Oughton C., Warby S. (Eds.), Football in the digital age: whose game is it anyway? Edinburgh: Mainstream Publishing, 28-35.

Breitbarth, T., \& Harris, P. (2008). The role of corporate social responsibility in the football business: towards the development of a conceptual model. European Sport Management Quarterly, 8(2), 179-206. https://doi.org/10.1080/16184740802024484

Brewer, J. D. (2000). Ethnography. Buckingham: Open University Press.

Bridoux, F., \& Stoelhorst, J. W. (2014). Microfoundations for stakeholder theory: Managing stakeholders with heterogeneous motives. Strategic Management Journal, 35(1), 107-125. https://doi.org/10.1002/smj.2089

Carroll, A. B. (1991). The pyramid of corporate social responsibility: toward the moral management of organizational stakeholders. Business Horizons, July-August: 30-48.

https://doi.org/10.1016/0007-6813(91)90005-g 
Carroll, A. B., \& Buchholtz, A. K. (2000). Business and society: ethics and stakeholder management. Cincinnati: South-Western Publishing.

Carroll, A. B., \& Näsi, J. (1997). Understanding stakeholder thinking: themes from a Finnish conference. Business Ethics: A European Review, 6(1), 46-51. https://doi.org/10.1111/1467-8608.00047

Clarkson, M. B. (1994). Arisk based model of stakeholder theory. Proceedings of the second Toronto conference on stakeholder theory. Centre for Corporate Social Performance \& Ethics, University of Toronto.

Clarkson, M. B. (1995). A stakeholder framework for analyzing and evaluating corporate social performance. Academy of Management Review, 20(1), 92-117.

Dahl, R. A. (1957). The concept of power. Behavioral Science, 2(3), 201-215. https://doi.org/10.1002/bs.3830020303

David, A. (2004). «Études de cas et généralisation scientifique en sciences de gestion », Actes de la XIIlème Conférence de l'Association Internationale de Management Stratégique, Le Havre.

Davies, B., Downward, P., \& Jackson, I. (1995). The demand for rugby league: evidence from causality tests. Applied Economics, 27(10), 1003-1007. https://doi.org/10.1080/00036849500000081

Deloitte. (2015). Deloitte football money league, January.

Denzin, N. K., \& Linclon, Y. S. (1994). Entering the field of qualitative research. In: Denzin N. K., Linclon Y. S. (Eds.), Handbook of qualitative research, Thousand Oaks: Sage Publications, 1-17.

Direction Nationale du Contrôle de Gestion (DNCG). (2015). Comptes individuels des clubs, saison 2014-2015.

Dodd, E. M. (1932). For whom are corporate managers trustees? Harvard Law Review, 45(7), 1145-1163. https://doi.org/10.2307/1331697

Drucker-Godard, C., Ehlinger, S., \& Grenier, C. (1999). Validité et fiabilité de la recherche. In: Thiétart R. A. (Ed.), Méthodes de recherche en management, Paris: Dunod, 257-287.

Eden, C., \& Ackermann, F. (1998). Making strategy: the journey of strategic management, London: Sage Publications.

Eisenhardt, K. (1989). Building theories from case study research. Academy of Management Review, 14(4), $532-550$.

Etzioni, A. (1964). Modern organizations. Englewood Cliffs: Prentice-Hall.

Eyestone, R. (1978). From social issue to public policy. New York: Wiley.

Freeman, R. E. (1984). Strategic management: a stakeholder approach. Boston: Pitman.

Freeman, R. E. (2006). The Wal-Mart effect and business, ethics and society. Academy of Management Perspectives, 20(3), 38-40. https://doi.org/10.5465/AMP.2006.21903479

Freeman, R. E., \& McVea, J. (2001). A stakeholder approach to strategic management. Working Paper, 01-02, Darden Graduate School of Business Administration, University of Virginia. https://doi.org/10.2139/ssrn.263511

Friedman, A., \& Miles, S. (2006). Stakeholders: theory and practice. Oxford: Oxford University Press.

Gibson, K. (2000). The moral basis of stakeholder theory. Journal of Business Ethics, 26(3), 245-257. https://doi.org/10.1023/A:1006110106408

Goddard, J., \& Sloane, P. J. (2005). Economics of sport. In: Bowmaker S. (Ed), Economics uncut: an alternative guide to the dismal science, Northampton: Edward Elgar, 345-366. https://doi.org/10.4337/9781845427986.00026

Hamil, S., Holt, M., Michie, J., Oughton, C., \& Shailer, L. (2004). The corporate governance of professional football clubs, Corporate Governance: The International Journal of Business in Society, 4(2), 44-51. https://doi.org/10.1108/14720700410534967

Harrison, J. S., \& St John, C. H. (1996). Managing and partnering with external stakeholders. Academy of Management Executive, 10(2), 46-60. https://doi.org/10.5465/ame.1996.9606161554

Harrison, J. S., \& St John, C. H. (1997). Strategic management of organizations and stakeholders. South-Western College Publishing, Cincinnati.

Healy, J. C., \& McDonagh, P. (2013). Consumer roles in brand culture and value co-creation in virtual 
$\begin{array}{lllll}\text { communities. Journal of } & \text { Business }\end{array}$ https://doi.org/10.1016/j.jbusres.2012.09.014

Hill, C. W. L., \& Jones, T. M. (1992). Stakeholder-agency theory. Journal of Management Studies, 29(2), 131-154. https://doi.org/10.1111/j.1467-6486.1992.tb00657.x

Jones, R. L., Armour, K. M., \& Potrac, P. (2003). Constructing expert knowledge: a case study of a top-level professional soccer coach, Sport, Education and Society, 8(2), 213-229. https://doi.org/10.1080/13573320309254

Krippendorff, K. (2003). Content analysis: an introduction to its methodology, Thousand Oaks: Sage Publications.

Lapassade, G. (2001). L'observation participante. Revue Européenne d'Ethnographie de l'Education, 1(1), 9-26.

Low, C., \& Cowton, C. (2004). Beyond stakeholder engagement: the challenges of stakeholder participation in corporate governance. International Journal of Business Governance and Ethics, 1(1), 45-55. https://doi.org/10.1504/IJBGE.2004.004896

Mendelow, A. (1991). Stakeholder mapping. Proceedings of the 2nd International Conference on Information Systems, Cambridge, MA.

Mercier, S. (2001). L'apport de la théorie des parties prenantes au management stratégique: une synthèse de la littérature, Xème Conférence de l'Association Internationale de Management Stratégique (AIMS), Université Laval, Québec, 13-15 juin.

Meyssonnier, F., \& Mincheneau, M. (2013). Le contrôle de gestion des clubs de football professionnel, Finance Contrôle Stratégie, 16(4), 63-81. https://doi.org/10.4000/fcs.1425

Michie, J., \& Oughton, C. (2005). The corporate governance of professional football clubs in England. Corporate Governance. An International Review, 13(4), 517-531. https://doi.org/10.1111/j.1467-8683.2005.00446.x

Miles, M. B., \& Huberman, A. M. (2003). Analyse des données qualitatives, Paris: De Boeck.

Mitchell, R. K., Agle, B. R., \& Wood, D. J. (1997). Towards a theory of stakeholder identification and salience: defining the principle of who and what really counts. Academy of Management Review, 22(4), 853-886. http://www.jstor.org/stable/259247

Moriceau, J. L. (2003). La répétition du singulier: pour une reprise du débat sur la généralisation à partir d'études de cas. Revue Sciences de Gestion, 36, 113-140.

Morrow, S. (2013). Football club financial reporting: time for a new model? Sport, Business and Management: An International Journal, 3(4), 297-311.

Opute, A. P. (2012). Maximizing effectiveness in team sports: the personal audit tool, Team Performance Management: An International Journal, 18(1/2), 78-101.

Paché, G., \& N'Goala, G. (2011). Les stratégies de création et d'appropriation de la valeur dans un contexte d'incertitude majeure: le cas du football professionnel. Management \& Avenir, 46, 53-78. https://doi.org/10.3917/mav.046.0053

Pfeffer, J. (1981). Power in organizations. Marshfield: Pitman.

Phillips, R. (2003a). Stakeholder legitimacy. Business Ethics Quarterly, 13(1), 25-41. https://doi.org/10.5840/beq20031312

Phillips, R. (2003b). Stakeholder theory and organizational ethics. San Francisco: Berret-Koelher Publishers.

Post, J., Preston, L., \& Sachs, S. (2002). Managing the extended enterprise: the new stakeholder view. California Management Review, 45(1), 6-28. https://doi.org/10.2307/41166151

Robert, A. D., \& Bouillaguet, A. (1997). L'analyse de contenu. Paris: Presses Universitaires de France.

Sarikaya, M., Yilmaz, S., \& Temizel, F. (2012). The need and corporate reputation in publicly traded sports corporations: examination of Beşiktaş Sports Inc. International Journal of Economics and Accounting, 3(1), 4-31. https://doi.org/10.1504/IJEA.2012.045520

Scarnati, J. T. (2001). On becoming a team player, Team Performance Management: An International Journal, 7(1/2), 5-10.

Senaux, B. (2004). Gouvernance des clubs de football professionnel: une approche partenariale, XIIlème 
Conférence de l'Association Internationale de Management Stratégique (AIMS), Le Havre, 2-4 juin

Senaux, B. (2008). A stakeholder approach to football club governance. International Journal of Sports Management and Marketing, 4(1), 4-17. https://doi.org/10.1504/IJSMM.2008.017655

Senaux, B. (2011). Playing by the rules but which ones? Sport, Business and Management: An International Journal, 1(3), 252-266.

Sloane, P. J. (1971). The economics of professional football: the football club as a utility maximizer. Scottish Journal of Political Economy, 18(2), 121-146. https://doi.org/10.1111/j.1467-9485.1971.tb00979.x

Sloane, P. J. (2006). The European model of sport. In: Andreff W, Szymanski S (Eds), Handbook on the economics of sport, Northampton: Edward Elgar, 299-303. https://doi.org/10.4337/9781847204073.00037

Soulé, B. (2007). Observation participante ou participation observante? Usages et justifications de la notion de participation observante en sciences sociales. Recherches Qualitatives, 27(1), 127-140.

Stake, R. E. (1994). Case Studies. In: Denzin N. K., Lincoln Y. S. (Eds), Strategies of qualitative inquiry, Thousand Oaks: Sage Publications, 86-109.

Stake, R. E. (1995). The art of case study research. Thousand Oaks: Sage Publications.

Suchman, M. C. (1995). Managing legitimacy: strategic and institutional approaches. Academy of Management Review, 20(3), 571-610.

Sugden, J. (2002). Network football. In: Sugden J., Tomlinson A. (Eds), Power games: a critical sociology of sport, London: Routledge, 61-80.

Svendsen, A. (1998). The stakeholder strategy: profiting from collaborative business relationships. San Francisco: Berrett-Koehler.

Walters, G. (2011). The implementation of a stakeholder management strategy during stadium development: a case study of Arsenal football club and the Emirates Stadium. Managing Leisure, 16(1), 49-64. https://doi.org/10.1080/13606719.2011.532600

Walters, G., \& Chadwick, S. (2009). Corporate citizenship in football: delivering strategic benefits through stakeholder engagement. Management Decision, 47(1), 51-66. https://doi.org/10.1108/00251740910929696

Walters, G., \& Tacon, R. (2010). Corporate social responsibility in sport: stakeholder management in the UK football industry. Journal of Management \& Organization, 16(4), 566-586. https://doi.org/10.1017/S1833367200001942

Wartick, S. L., \& Mahon, J. M. (1994). Toward a substantive definition of the corporate issue construct: a review and synthesis of the literature. Business \& Society, 33(3), 293-311. https://doi.org/10.1177/000765039403300304

Weber, M. (1947). The theory of social and economic organization. New York: Free Press.

Weiss, J. W. (1994). Business ethics: a managerial stakeholder approach. Belmont: Wadsworth.

Westre, K. R., \& Weiss, M. R. (1991). The relationship between perceived coaching behaviors and group cohesion in high school football teams, The Sport Psychologist, 5(1), 41-54. https://doi.org/10.1123/tsp.5.1.41

Williamson, O. E. (1985). The economic institutions of capitalism. New York: Free Press.

Wood, D. J. (1991). Corporate social performance revisited. Academy of Management Review, 16(4), 691-718.

Yin, R. K. (2011). Applications of case study research, Thousand Oaks: Sage Publications.

Yin, R. K. (2013). Case study research: design andmethods, Thousand Oaks: Sage Publications.

Zimbalist, A. (2003). Sport as business. Oxford Review of Economic Policy, 10(4), 503-511. https://doi.org/10.1093/oxrep/19.4.503

\section{Copyrights}

Copyright for this article is retained by the author(s), with first publication rights granted to the journal.

This is an open-access article distributed under the terms and conditions of the Creative Commons Attribution license (http://creativecommons.org/licenses/by/4.0/). 